\title{
Вытекание излучения из волноводных микроструктур, обладающих определенным типом дискретной вращательной симметрии оболочки
}

\author{
А.Д. Прямиков" \\ Научный иентр волоконной оптики РАН \\ *E-mail: pryamikov@fo.gpi.ru
}

DOI:10.31868/RFL2018.172-173

В настоящее время полые микроструктурированные световоды (ПМС) находят применения в различных прикладных и фундаментальных областях исследований. Изначально, данное направление волоконной оптики базировалось на двух основных типах ПМС: полых брэгговских световодах и полых ПМС с фотонно - кристаллической оболочкой, представляющей собой двумерный фотонный кристалл со сложной периодической структуройрасположения микро нано элементов в оболочке.Структура оболочки необходимая для распространения света с малыми потерями на данной длине волны в брэгговском ПМС подбирается таким образом, что в отражающих слоях с более высоким показателем преломления должно выполняться антирезонансное условие для поперечной составляющей волнового вектора $k_{t} d=\pi(m+1 / 2)$. В данном случае, $d$ - это толщина рассматриваемого слоя оболочки, а $m$ - целое число. Так как границы слоев оболочки представляют собой простые окружности, то антирезонансное условие для поперечной компоненты волнового вектора одинаково вдоль всего периметра границы и проекция поперечной компоненты вектора Пойнтинга моды полой сердцевины на радиус вектор в рассматриваемой точке границы всегда положительно. Модель, описывающая локализацию света в таких ПМС, называется моделью ARROW [antiresonant optical waveguide] [1]. Процесс локализации света в полой сердцевине в фотонно - кристаллическом ПМС более сложен. В данном случаеколичество типов микро и нано элементов различной формы в микроструктурированной оболочке световода, от которых происходит отражение излучения, значительно больше, чем в случае брэгговского ПМС. Поэтому ширина зон пропускания излучения в полой сердцевине, определяемые собственными частотами этих резонаторов, может быть уже, чем в случае брэгговских световодов, в которых границы зон пропускания определяются только поперечными резонансами в отдельном слое оболочки. Это, в свою очередь, определяет уровень потерь в данном диапазоне пропускания и наклон дисперсионной кривой мод полой сердцевины. Но так как форма границы сердцевина - оболочка в таком ПМС также имеет форму окружности, то антирезонансное условие для поперечной компоненты волнового вектора также одинаково вдоль ее периметра.

ПМС нового типа, не имеющие структуры фотонного кристалла в оболочке, с оболочкой, состоящей из одного ряда капилляров, получили название ПМС с отрицательной кривизной границы сердцевина - оболочка (ПМС с ОКГСО) (negative curvature hollow core fibers) [2]. Как показали эксперименты, ПМС данного типа значительно лучше локализует свет в полой сердцевине по сравнению с рассмотренными выше ПМС. 

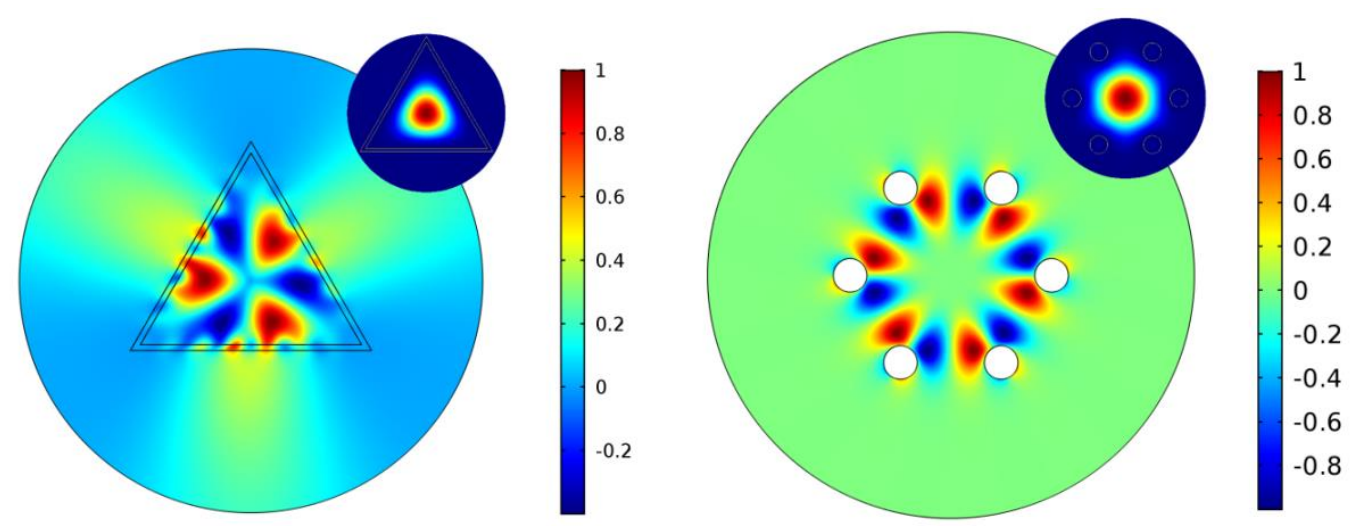

Рис. 1. (левый) распределение проекции поперечной компоненты вектора Пойнтинга основной моды полой сердцевины треугольного ПМС на радиус вектор, проведенный в данную точку поперечного сечения, (вставка) распределение аксиальной компоненты вектора Пойнтинга основной моды; (правый) аналогичное распределение для полностью твердотельного волновода с оболочкой, состоящей из шести стержней.

Подобного рода поведение может говорить о том, что условия отражения излучения мод полой сердцевины на границе сердцевина - оболочка и его вытекание в оболочку ПМС с ОКГСО, отличаются от аналогичных условий в ПМС, рассмотренных выше, так как граница сердцевина - оболочка имеет в случае ПМС с ОКГСО определенную вращательную симметрию. В наших недавних работах [3,4] было показано, что проекция поперечной компоненты вектора Пойнтинга основной моды полой сердцевины на проведенный в данную точку границы сердцевина - оболочка радиус - вектор, имеет особенности, связанные с периодическим изменением знака вдоль границы. Эти особенности показаны на Рис. 1 (левый) для простого полого волновода треугольной формы (стенки границы состоят из кварцевого стекла, а ее толщина порядка длины волны, в данном случае 1 мкм). Как видно из Рис. 1, такая проекция поперечной компоненты вектора Пойнтинга меняет знак вдоль границы, причем число областей с переменным знаком явно согласуется с вращательной симметрий границы волноводной системы. Другой пример (Рис. 1(правый)) показывает, что подобного рода поведение поперечной компоненты вектора Пойнтинга присуще не только ПМС, но и обычным микроструктурированным световодам (МC). В данном случае рассмотрен простейший пример - полностью твердотельный МС c оболочкой из шести стержней с более высоким показателем преломления, чем окружающая их кварцевая матрица. При этом проекция поперечной компоненты потока также меняет знак в согласии с типом вращательной симметрии расположения элементов оболочки.

\section{Литература}

[1] F. Prieto, et. al, J. Lightwave Technology, 18, 966 - 972 (2000)

[2] A. D. Pryamikov, et. al, Opt. Express, 19, $1441-1448$ (2011)

[3] A. D. Pryamikov and G. K. Alagashev, Fibers, 5, 43 (2017)

[4] A. D. Pryamikov and G. K. Alagashev, Opt. Engineering, 57, 066106 (2018) 